\title{
The effectiveness of asexual and sexual reproduction in clonal species Dianthus superbus L. in different site conditions - the consequences for population development
}

\author{
Kinga Kostrakiewicz-Gieralt
}

Department of Plant Ecology, Institute of Botany, Jagiellonian University, Lubicz 46, 31-512 Kraków, Poland, e-mail: kinga.kostrakiewicz@uj.edu.pl

\begin{abstract}
The effectiveness of asexual and sexual reproduction of rare, clonal species Dianthus superbus L. were conducted in the years 2008-2010 in Kostrze (Southern Kraków). The observations were carried out in Molinietum caeruleae patches dominated by small species creating delicate, erect or procumbent stems (MC), prevailed by tall grasses (GR), and overgrown by willows (SA). The number of above-ground units per ramet cluster were much greater in MC patch, than in sites GR and SA. Controversially, the number of fruit per generative shoot and seed production were greater in GR and SA patches, than in MC patch. The highest seedling recruitment, occurring only in artificially created gaps in plant canopy and litter was noted in patch MC, while the decline of genet emergence were found in SA and GR patches.

In light of performed studies, it should be concluded, that population established in patch dominated by small meadow species has the greatest chance for survival, whereas populations inhabiting sites prevailed by tall grasses or overgrown by willows have much lower possibilities of persistence in occupied places.
\end{abstract}

Key words: above-ground unit, generative propagation, ramet cluster, seedling recruitment, vegetative multiplication.

\section{Introduction}

The advantage of clonal plants over nonclonal species in colonization of various habitats primarily is due to occurrence of two ways of reproduction (Klimešova et al. 1997). The asexual propagation produces new ramets by budding from roots, rhizomes, stems, storage organs or inflorescences (Silvertown 2008). The vegetative multiplication enables an individual to expand, monopolize resources, and in consequence prolongs its survival in the newly colonized site. The generative reproduction allows recruitment of new genets and ensures the genetic diversity of the population. Although large body of literature illustrates correlation between two manner of propagation reviewed by Obeso (2002), Zhang and Zhang (2007), and Lei (2010), there is still much room for further research on this issue. Zhang and Zhang (2007) expected, that effect of disturbed and competitive environment on relation between reproductive modes and their implications for the population development should attract more attention in future studies. Especially, the investigations taking into account the reproductive strategies of endangered taxa, providing a basis for efficient protection programs, are strongly needed.

In Poland one of the rare and strictly protected clonal plants with a requirement for active conservation (Rozporządzenie 2012) and included to Red List of Vascular Plants in Poland (Zarzycki \& Szeląg 2006) is Dianthus superbus L. The large pink is listed as a species of the Euro-siberian sub-element, widely but patchily distributed in western, central and eastern Europe, as well as northern Asia (Meusel et al. 1965). In Poland the greatest number of localities occurs in the Vistula valley, whereas the lowest density of stands are recorded in the Baltic coastal area and western Pomerania (Zając \& Zając 2001). Populations of 
the large pink are found in wet and semi-wet meadow communities of the order Molinietalia (Matuszkiewicz 2001). Dianthus superbus L. is a loosely tufted perennial forb, consisted of numerous vegetative stems and tall generative shoots topped with many flowers pollinated by insects. Greenish, four-valved capsules contain self-sowing seeds. The asexual reproduction of large pink consists of the proliferation of individuals followed by their fragmentation (Klimešová \& Klimeš 2006). Therefore, the objective of presented study was to learn the effect of site conditions on the effectiveness of asexual and sexual reproduction in Diantus superbus L.

\section{Study area}

The studies were carried out in Kostrze district localised on western edge of Krakow, south of the Vistula River (southern Poland). The patches of Molinietum caeruleae occuring in this locality are relicts of vast meadows, which existed along Vistula river from Czernichów, west of Kraków to Niepołomice Forest (Zarzycki 1956, 1958). The abandonment of traditional land use for at least a dozen years promoted the development of Phragmites swamps and willow brushwood leading to fragmentation of meadows (Dubiel 1991, 1996). The studies were carried out simultaneously in three adjacent, abandoned patches $M o$ linietum caeruleae with different species composition and habitat conditions. Patch labeled MC (50 $01^{\circ} 50.4$ ' $\mathrm{N}$, $19^{\circ} 52^{\prime}$ 03.2' E) measured ca $1400 \mathrm{~m}^{2}$ and unmanaged from $\mathrm{ca} 10$ years was dominated by taxa presenting minor competitive ability. These were species creating delicate, erect or procumbent stems (i.e. Lathyrus pratensis., Lotus corniculatus), small-tussock grasses (i.e. Briza media, Holcus lanatus) and short rosette-forb species (i.e. Lychnis flos-cucculi, Succisa pratensis). The small-statured taxa covered $c a 60 \%$ of Patch and intercepted very low amount of irradiance, contributing to strong insolation and the fast decrease of groundwater level in early spring. Patch called GR (50 01 ' $52.5^{\circ}$ ' $\mathrm{N}, 1^{\circ} 52^{\prime} 03.0$ " E) measured $c a 1$ $300 \mathrm{~m}^{2}$ and abandoned from 15 years was prevailed by tall grasses forming large tussocks (i.e. Molinia caerulea, Deschampsia cespitosa) or robust rhizomes (i.e. Phragmites australis). The tall-growing grasses covered approximately $55 \%$ of patch area. The high, closely packed shoots shaded whole patch, whereas the hummock and hollows microtopography triggered the stagnation of water in local depressions, particularly in spring and autumn. Patch named SA (50 01' 50.9" N, $19^{\circ} 52^{\prime} 02.9$ ' E) measured ca $1450 \mathrm{~m}^{2}$ was unmanaged from 18 years. It was overgrown by willows (i.e. Salix repens ssp. rosmarinifolia., S. cinerea, S. aurita) and surrounded by groups of densely grown trees (i.e. Populus tremula., Betula pendula) and bushes (Crataegus sp.). Altogether, the cover of willows, trees and shrubs amounted $c a 65 \%$ of Patch area. The wide and spreading willow leaves strongly prevented the solar radiation.

\section{Material and methods}

A genet and a cluster of ramets were adopted as the basic demographic units. A genet (genetic individual) is a plant emerged from a single zygote. This term was applied to plants in earlier stages of development, because only at these stages could it be established for sure that they had developed from the same zygote. The term "cluster of ramets" means an aggregation of generative shoots and vegetative stems formed in the course of vegetative proliferation of genet or genets. The term "ramet" denotes a single vegetative stem or generative shoot (Falińska 2002).

The field research were carried out in the period 20082010. In the year 2008, all ramet clusters occurred in studied patches were ringed and marked with small, numbered plastic pegs. Every year the efficacy of asexual and sexual reproduction were examined. The effectiveness of vegetative multiplication was estimated on the basis of abundance of above-ground units per ramet cluster. In order to investigate the efficacy of generative propagation the number of fruits, seed production and natural seedling recruitment were observed. The number of capsules were assessed in each generative shoot. The seed output were evaluated in 25 capsules randomly chosen in each patch. After counting, all seeds were scattered near ramet clusters, from which they were collected. Subsequently, the spontaneous recruitment of seedlings were studied in experimentally created gaps. In order to assess this in April 2008 in each patch were randomly arranged 10 permanent experimental $0.5 \mathrm{x}$ $0.8 \mathrm{~m}$ plots, established at least 2.0 metres from the border of patch to avoid edge effect. Each plot was divided in two square shaped, adjacent subplots measuring $900 \mathrm{~cm}^{2}$. In one of these the established vegetation and litter left untouched, while in the second plant canopy and decayed organic matter were clipped and removed. Such treatment is considered as optimal for seedling establishment on the basis of result of experiments carried out in wet meadows (Kotorová \& Lepš 1999). The generative offspring establishment was monitored once a week in May, June, July, as well as August and twice a month in April, September and October. The seedlings were removed and determined according to Csapodý (1968) and Muller (1978) with support of comparative collection. After identification all genets of Dianthus superbus were replanted and marked with plastic sticks. The seedling recruitment was monitored throughout the three seasons.

The statistical analysis of not transformed data applied the nonparametric Kruskal-Wallis test, used to check if there are differences in numbers of above-ground units per 
ramet cluster, fruit per generative shoot, seeds per capsule, and seedlings per subplots among studied patches in consecutive years.

\section{Results}

The abundance of studied populations were similar and reached 13 ramet clusters in patch MC (dominated by small meadow species), 15 ramet clusters in patch GR (prevailed by large-tussock grasses) and 10 ramet clusters in patch SA (overgrown by willows). The greatest effectiveness of asexual reproduction was found in MC patch, and it decreased gradually in patches GR and SA. The number of above-ground units per ramet cluster in $\mathrm{MC}$ patch reached from 6.4 to 11.3 , in patch GR it achieved from 5.4 to 8.4 , while in site SA it amounted from 4.7 to 6.2 (Table 1). Controversially, much greater fruit and seed production were recorded in patches SA and GR, than in $\mathrm{MC}$ site. The average capsule number in patch SA reached from 12.0 to 13.5 , in site GR it achieved from 10.2 to 11.3, whereas in patch MC it amounted from 5.8 to 6.4 (Table 2). The number of seeds per fruit in patch SA reached from 57.9 to 62.3 , in site GR it achieved from 55.1-61.4, while in place MC it amounted from 43.0 to 46.6 (Table 3). In all populations the seedlings appearance were recorded only in openings in plant canopy and litter. The highest seedling number were found in patch $\mathrm{MC}$, where reached on average from 2.5 to 2.7 . The lower recruitment values were noted in patches GR (from 0.6 to 0.9 ) and SA (from 0.8 to 1.2 ) (Fig. 1 ).

Table 1. The number of above-ground units of marked ramet clusters of Dianthus superbus L. in patches dominated by small meadow species (MC), prevailed by grasses with high stems (GR) and overgrown by willows (SA) in the period 2008-2010. Significance levels obtained by Kruskal-Wallis test $(\mathrm{df}=2)$ are as follows: ${ }^{\text {ns }}-$ not significant, $*=p<0.05$. The different letters assigned to average values indicate the significant statistical difference between populations

\begin{tabular}{ccccc}
\hline Year & Patch & $\begin{array}{c}\text { Average } \\
\text { value }\end{array}$ & Range & $\begin{array}{c}\text { The statistical significance } \\
\text { level (H Kruskal-Wallis test) }\end{array}$ \\
\hline \multirow{2}{*}{2008} & MC & $6.4^{\mathrm{a}}$ & $3-13$ & \\
& GR & $5.4^{\mathrm{a}}$ & $1-20$ & $4.46^{\mathrm{ns}}$ \\
& SA & $4.7^{\mathrm{a}}$ & $1-11$ & \\
\hline \multirow{4}{*}{2009} & MC & $8.3^{\mathrm{a}}$ & $3-14$ & \\
& GR & $6.6^{\mathrm{a}}$ & $1-25$ & $4.10^{\mathrm{ns}}$ \\
& SA & $5.8^{\mathrm{a}}$ & $1-15$ & \\
\hline \multirow{2}{*}{2010} & MC & $11.3^{\mathrm{b}}$ & $6-18$ & \\
& GR & $8.4^{\text {ab }}$ & $3-27$ & $9.58^{*}$ \\
& SA & $6.2^{\mathrm{a}}$ & $2-14$ & \\
\hline
\end{tabular}

Table 2. The number of fruits per sexual shoots in marked ramet clusters of Dianthus superbus L. in patches dominated by small meadow species (MC), prevailed by grasses with high stems (GR) and overgrown by willows (SA) in the period 2008-2010. Significance level obtained by Kruskal-Wallis test $(\mathrm{df}=2)$ are as follows: $*=p<0.05$, $* *=p<0.01$. The different letters assigned to average values indicate the significant statistical difference between populations

\begin{tabular}{ccccc}
\hline Year & Patch & $\begin{array}{c}\text { Average } \\
\text { value }\end{array}$ & Range & $\begin{array}{c}\text { The statistical significance } \\
\text { level (H Kruskal-Wallis test) }\end{array}$ \\
\hline \multirow{2}{*}{2008} & MC & $5.8^{\text {a }}$ & $3-9$ & \\
& GR & $10.2^{\text {b }}$ & $4-28$ & $12.78^{*}$ \\
& SA & $12.5^{\text {b }}$ & $4-36$ & \\
\hline & MC & $6.4^{\text {a }}$ & $4-10$ & $14.14^{* *}$ \\
\hline \multirow{2}{*}{2009} & GR & $11.1^{\mathrm{b}}$ & $3-30$ & \\
& SA & $12.0^{\mathrm{b}}$ & $4-36$ & $15.06^{* *}$ \\
& MC & $5.9^{\mathrm{a}}$ & $2-9$ & \\
\hline & GR & $11.3^{\mathrm{b}}$ & $2-38$ & \\
& SA & $13.5^{\mathrm{b}}$ & $3-38$ & \\
\hline
\end{tabular}

Table 3. The seed production in 25 capsules of Dianthus superbus L. in patches dominated by small meadow species (MC), prevailed by grasses with high stems (GR) and overgrown by willows (SA) in the period 2008-2010. Significance levels obtained by Kruskal-Wallis test $(\mathrm{df}=2)$ are as follows: $* *=\mathrm{p}<0.01, * * *=\mathrm{p}<0.001$. The different letters assigned to average values indicate the significant statistical difference between populations

\begin{tabular}{ccccc}
\hline Year & Patch & $\begin{array}{l}\text { Average } \\
\text { value }\end{array}$ & Range & $\begin{array}{l}\text { The statistical significance } \\
\text { level (H Kruskal-Wallis test) }\end{array}$ \\
\hline \multirow{2}{*}{2008} & MC & $45.84^{\text {a }}$ & $25-67$ & $13.10^{* *}$ \\
& GR & $61.48^{\text {b }}$ & $35-83$ & \\
& SA & $57.96^{\text {b }}$ & $27-71$ & $21.53^{* * *}$ \\
\hline \multirow{2}{*}{2009} & MC & $43.04^{\text {a }}$ & $28-77$ & \\
& GR & $57.64^{\text {b }}$ & $14-98$ & \\
\hline \multirow{4}{*}{2010} & SA & $62.36^{\text {b }}$ & $32-78$ & $13.57^{* * *}$ \\
& MC & $46.56^{\text {a }}$ & $38-60$ & \\
& SA & $65.71^{\text {ab }}$ & $22-89$ & \\
\hline
\end{tabular}




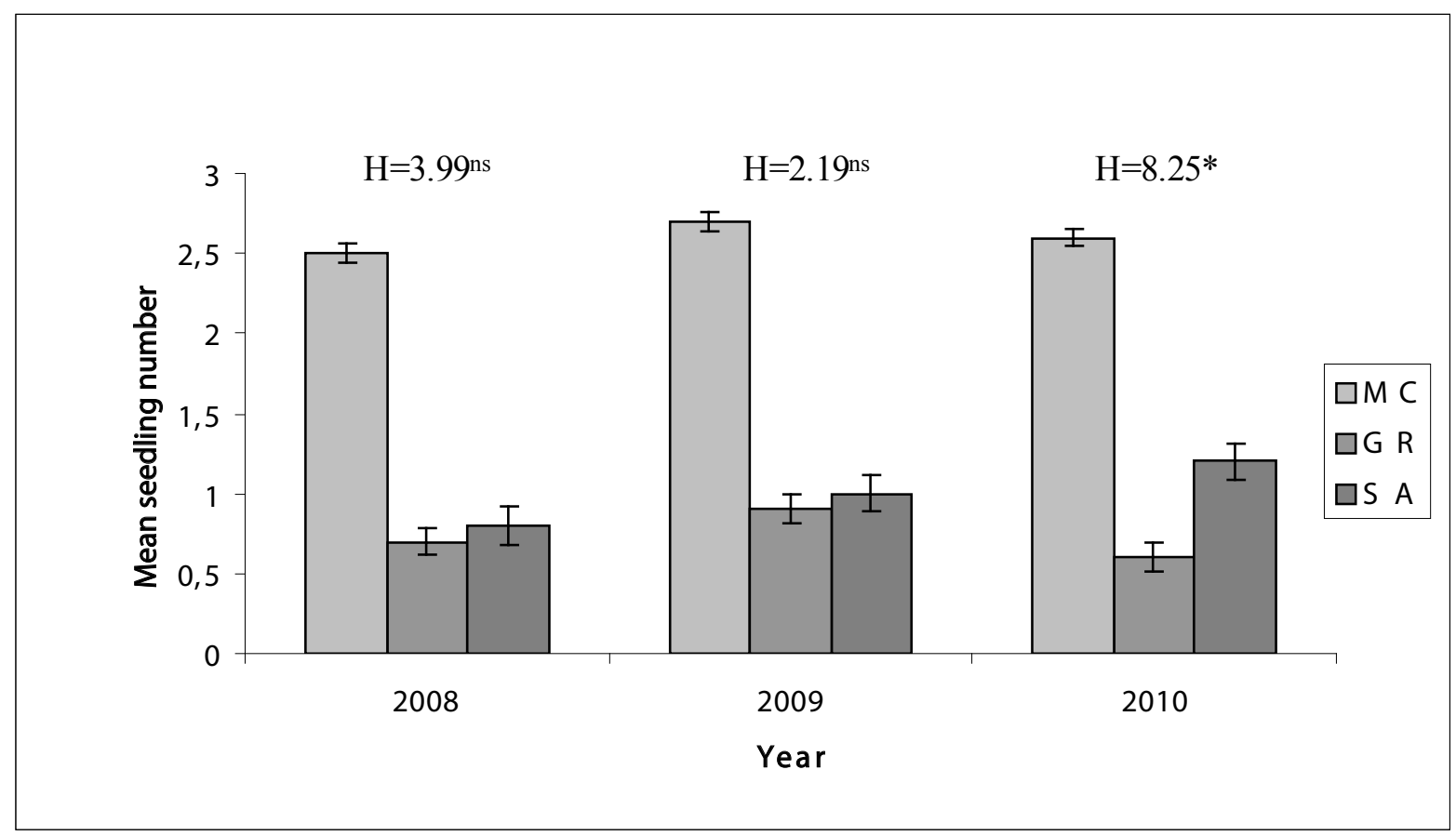

Figure 1. The mean number of seedlings of Dianthus superbus L.( \pm standard error) in experimental gaps in patches dominated by small meadow species (MC), prevailed by grasses with high stems (GR) and overgrown by willows (SA) in the period 2008-2010. Significance levels obtained by Kruskal-Wallis test $(\mathrm{df}=2)$ are as follows: ${ }^{\text {ns }}-$ not significant, $*=p<0.05$

\section{Discussion}

The effectiveness of vegetative multiplications vs. fruit and seed production, being evolutionary adaptation to environmental conditions, may vary widely among species. Holler and Abrahamson (1977) detected strong effect of competition level on vegetative proliferation and no influence on seed reproductive effort. Pluess and Stöcklin (2005) noted that in plants growing in the competition-free habitat the generative reproduction is greater than the clonal propagation, whereas individuals from crowded sites present the opposite tendency. Other findings brought evidence that rising of competition intensity might contribute to suppression of clonal multiplication and seed output (Jurik 1985; Rautiainen et al. 2004) or the increase of vegetative proliferation, as well as diaspore production (Coelho et al. 2005).

The investigations performed in Dianthus superbus L. populations showed the gradually diminishing of vegetative multiplication and augmentation of fruit and seed production with increase of competition gradient. The raising investment into generative reproduction and the diminishing of allocation in clonal propagation in crowded habitats was observed in Lychnis flos-cuculi (Chaloupecká \& Lepš 2004). Similar phenomenon were also noted in populations of Ranunculus repens (van Kleunen et al. 2001),
Hieracium pilosella L (Winkler \& Stöcklin 2002), Scirpus olneyi A. Gray (Ikegami et al. 2004) and Iris sibirica L. (Kostrakiewicz 2007). Furthermore, presented findings stay in accordance with predictive models Newell and Tramer (1978), as well as Takada and Nakajima (1996). Above mentioned authors stated, that clonal growth should be dominant in stable habitats, while sexual reproduction prevails in sites with fluctuating environmental conditions and strong competition. Also, Loechle (1987), as well as Gardner and Mangel (1999) expected, that a higher allocation to fruit and seed production under high density allows to disperse from locally adverse conditions and colonize new, richer and more favorable sites.

The obtained results demonstrating higher seedling appareance in MC patch, than in GR and SA sites, are consistent with previous studies on recruitment of Dianthus superbus L., Gladiolus imbricatus L., Iris sibirica L., Gentiana pneumonanthe L. and Trollius europaeus L. in Molinietum caeruleae meadows (Kostrakiewicz 2010). The greatest genet performance observed in MC patch might be due to appearance safe sites suitable for recruitment in result of decrease of groundwater table in early spring and top soil insolation. The weaker colonization of openings in other patches might be consequence of shading by standing vegetation, as well as prolonged water stagnation in local depressions occurred in sites GR and SA. 
In light of performed studies, it should be concluded, that population established in patch dominated by small meadow species has the greatest chance for survival due to high efficiency of asexual propagation. A lower fruit and seed production is compensated by the highest seedling number. In contrary, populations inhabiting patches prevailed by grasses and overgrown by willows have much lower possibilities of persistence in occupied sites in result of weaker effectiveness of vegetative propagation, as well as low recruitment rates.

\section{References}

Chaloupecká E. \& Lepš J., 2004, Equivalence of competitor effects and trade off between vegetative multiplication and generative reproduction: case study with $\mathrm{Lych}$ nis flos-cuculi and Myosotis nemorosa, Flora 199(2): 157-167.

Coelho F. F., Deboni L. \& Lopes F. S., 2005, Density-dependent reproductive and vegetative allocation in the aquatic plant Pistia stratioides (Araceae), International Journal of Tropical Biology 53: 369-376.

Csapodý V., 1968, Keimlingsbestimmungsbuch der Dikotyledonen, Akademiai Kiado, Budapeszt.

Dubiel E., 1991, Mapa roślinności rzeczywistej miasta Krakowa [Map of actual vegetation of the city of Cracow], Zeszyty Naukowe UJ, Prace Botaniczne 22: 121-133.

Dubiel E., 1996, Łąki Krakowa. I Klasa Molinio-Arrhenatheretea [Meadows in Cracow. I. Molinio-Arrhenatheretea class], Studia Ośrodka Dokumentacji Fizjograficznej 24: 145-171.

Falińska K., 2002, Przewodnik do badań biologii populacji roślin, Państwowe Wydawnictwo Naukowe, Warszawa.

Gardner S. N. \& Mangel M., 1999, Modeling investments in seeds, clonal offspring, and translocation in a clonal plant, Ecology 80: 1202-1220.

Holler L. C. \& Abrahamson W. G., 1977, Seed and vegetative reproduction in relation to density in Fragaria virginiana (Rosaceae), American Journal of Botany 64(8): 1003-1007.

Ikegami M., Whigham D. F. \& Werger M. J. A., 2004, Density effects on seed and vegetative propagation of Scirpus olneyi A. Gray, [in:] M. Ikegami (ed.), Functional specialization of ramets in a clonal plant network, Proefschrift Universiteit, Utrecht: 41-52.

Jurik T. W., 1985, Differential costs of sexual and vegetative reproduction in wild strawberry populations, Oecologia 66(3): 394-403.

Klimešová J. \& Klimeš L., 2006, Clo-Pla 3 - database of clonal growth of plants from Central Europe, Available from: http://clopla.butbn.cas.cz/
Klimešová J., Hendriks R. \& van Groenendael J., 1997, Clonal plant architecture: a comparative analysis of form and function, [in:] H. de Kroon, J. van Groenendael (eds), The ecology and evolution of clonal plants, Backhuys Publishers, Leiden, The Netherlantds: 1-29.

Kostrakiewicz K., 2007, The effect of dominant species on numbers and age structure of Iris sibirica L. population on blue moor-grass meadow in Southern Poland, Acta Societatis Botanicorum Poloniae 76: 165-173.

Kostrakiewicz K., 2010, Wpływ luk na rekrutację siewek ginących gatunków w płatach łąk trzęślicowych Molinietum caeruleae W. Koch 1926 [The effect of gaps on seedling recruitment of threatened species in Molinietum caeruleae W. Koch 1926 patches], Chrońmy Przyrodę Ojczystą 66: 184-189.

Kotorová I. \& Lepš J., 1999, Comparative ecology of seedlings recruitment in an oligotrophic wet meadow, Journal of Vegetation Science 10: 175-186.

Lei S. A., 2010, Benefits and Costs of Vegetative and Sexual Reproduction in Perennial Plants: A Review of Literature, Journal of the Arizona-Nevada, Academy of Science 42: 9-14.

Loechle C., 1987, Partitioning of reproductive effort in clonal plants: a benefit-cost model, Oikos 49: 199-208.

Matuszkiewicz W., 2001, Przewodnik do oznaczania zbiorowisk roślinnych Polski [Guide to identification of plant communities of Poland], Państwowe Wydawnictwo Naukowe, Warszawa.

Meusel H., Jäger E. \& Weinert E., 1965, Vergleichende Chorologie der Zentraleuropäischen Flora Bd. I Gustav Fisher, Jena.

Muller F. M., 1978, Seedlings of the North-Western European lowland. A flora of seedlings, Dr W. Junk B. V. Publishers, The Hague, Boston, Centre for Agricultural Publishing and Documentation, Wageningen.

Newell S. J. \& Tramer E. J., 1978, Reproductive strategies in herbaceous plant communities during succession, Ecology 59: 228-234.

Obeso J. R., 2002, The costs of reproduction in plants, New Phytologist 155: 321-348.

Rautiainen P., Koivula K. \& Hyvarinen M., 2004, The effect of within-genet and between genet competition on sexual reproduction and vegetative spread in Potentilla anserina ssp. egedii, Journal of Ecology 92: 505-511.

Pluess A. R. \& Stöcklin J., 2005, The importance of population origin and environment on clonal and sexual reproduction in the alpine plant Geum reptans, Functional Ecology 19: 228-237.

Rozporządzenie Ministra Środowiska z dnia 5 stycznia 2012 r. w sprawie ochrony gatunkowej roślin [Regulation of the Minister of Environment of 5 January 2012 on the plant species protection.], Dziennik Ustaw 2012, poz. 81 . 
Silvertown J., 2008, The evolutionary maintenance of sexual reproduction: evidence from the ecological distribution of asexual reproduction in clonal plants, International Journal of Plant Sciences 169: 157-168.

Takada T. \& Nakajima H., 1996, The optimal allocation for seed reproduction and vegetative reproduction in perennial plants: an application to the density-dependent transition matrix model, Journal of Theoretical Biology 182: 179-191.

van Kleunen M., Fischer M. \& Schmid B., 2001, Effects of intraspecific competition on size variation and reproductive allocation in a clonal plant, Oikos 94: 515-524.

Winkler E. \& Stöcklin J., 2002, Sexual and Vegetative Reproduction of Hieracium pilosella L. under Competition and Disturbance: a Grid-based Simulation Model, Annales of Botany 89: 525-536.

Zając A. \& Zając M. (eds.), 2001, Atlas rozmieszczenia roślin naczyniowych $\mathrm{w}$ Polsce [Distribution Atlas of Vascular Plants in Poland], Nakładem Pracowni
Chorologii Komputerewej Instytutu Botaniki Uniwersytetu Jagiellońskiego [Edited by Laboratory of Computer Chorology, Institute of Botany, Jagiellonian University], Kraków.

Zarzycki K., 1956, O zachowanie wilgotnych łąk w Dolinie Górnej Wisły, Chrońmy Przyrodę Ojczystą 12:11-17.

Zarzycki K., 1958, Wilgotne łąki w okolicach Czernichowa i potrzeba ich ochrony [Humid meadows in the environs of Czernichów near Cracow deserving protection], Ochrona Przyrody 25: 49-68.

Zarzycki K. \& Szeląg Z., 2006, Red List of Vascular Plants in Poland, [in:] Z. Mirek, K. Zarzycki, W. Wojewoda, Z. Szeląg (eds.), Red List of Plants and Fungi in Poland, W. Szafer Institute of Botany, Polish Academy of Sciances, Kraków: 9-20.

Zhang Y. \& Zhang D., 2007, Asexual and sexual reproductive strategies in clonal plants, Frontiers of Biology in China 2: 253-262. 